\title{
Efficacy of Pilot-Scale Wastewater Treatment upon a Commercial Recirculating Aquaculture Facility Effluent
}

\author{
Simonel Sandu ${ }^{1}$, Brian Brazil ${ }^{2,3}$ and Eric Hallerman ${ }^{1}$ \\ ${ }^{1}$ Virginia Polytechnic Institute and State University \\ ${ }^{2} U$ U.S. Department of Agriculture - Agricultural Research Service \\ ${ }^{3}$ Geosyntec Consultants, N.W., Kennesaw, GA
}

USA

\section{Introduction}

Recirculating aquaculture systems have been developed to produce high-value species for year-round supply of markets, to free production from site-related constraints, to minimize environmental impacts of aquaculture, and to make efficient use of limited high-quality water supplies. Effective treatment and reuse of aquaculture effluent has been demonstrated at an experimental scale. Blue Ridge Aquaculture (BRA, Martinsville, Virginia, USA) is a commercial venture producing 1360 metric tons of hybrid tilapia (Oreochromis sp.) per year in recirculating aquaculture systems. To our knowledge, BRA is the largest recirculating aquaculture enterprise under one roof in existence. Increased production at BRA is constrained by the availability of high-quality influent water. Meanwhile, BRA discharges an estimated $2290 \mathrm{~m}^{3}$ of wastewater per day to the municipal sewer system, equivalent to an average of $1 \mathrm{~m}^{3}$ discharged per $3.0 \mathrm{~kg}$ feed. Importantly, discharge of this effluent also loses heat energy, as water temperature is maintained at about $28-30^{\circ} \mathrm{C}$ to optimize tilapia growth. Concerned about the reliability and costs of their wells and the city water system, BRA seeks a technical solution. Developing a wastewater treatment system that recovers and reuses the water presently discharged could minimize these problems. The discharge issues faced by BRA typify intensive aquaculture, and evaluation of possible treatment strategies would have general interest to the aquaculture sector.

The BRA waste stream was characterized over eight-hour sampling periods during 12 different days. The results indicated that solids, chemical oxygen demand (COD), and nitrate were the most significant waste components by concentration and weight. All these forms of pollutants were targeted by unit processes in a treatment train. Following an ozone treatability study (Sandu, 2004), a pilot-scale wastewater treatment station was built in order to initiate, characterize and optimize the operation of this more complex treatment strategy. The ultimate goal was to obtain an effluent clean enough to be reused in the recirculating systems. The need to eliminate settable solids, colloids, dissolved organic substances and nitrogenous compounds led to selection of a sequential treatment process employing physical, biological, chemical, and again, biological steps. The performance of the pilot-scale wastewater treatment train with regard to solids and carbonaceous compounds was 
reported by Sandu et al. (2008). Here, we: (1) evaluate the effectiveness of a pilot wastewater treatment train with regard to alkalinity, $\mathrm{pH}$, hardness, and nitrogenous compounds (TAN, $\mathrm{NO}_{2}-\mathrm{N}, \mathrm{NO}_{3}^{--\mathrm{N}}$ and $\mathrm{TKN}$ ), (2) the effect of nitrate feed rate on denitrification, and (3) examine the economic feasibility of treating and reusing this aquaculture wastewater. All abbreviations used in this chapter are presented in Table 1.

\begin{tabular}{|c|c|}
\hline BRA & Blue Ridge Aquaculture \\
\hline BOD & biochemical oxygen demand $(\mathrm{mg} / \mathrm{l})$ \\
\hline $\mathrm{cBOD}_{5}$ & carbonaceous biochemical oxygen demand (mg/l) \\
\hline $\mathrm{CF}$ & chemical flocculation \\
\hline COD & chemical oxygen demand (mg/l) \\
\hline DR & denitrification reactor \\
\hline $\mathrm{NO}_{2}-\mathrm{N}$ & nitrite-nitrogen $(\mathrm{mg} / \mathrm{l})$ \\
\hline $\mathrm{NO}_{3}-\mathrm{N}$ & nitrate-nitrogen $(\mathrm{mg} / \mathrm{l})$ \\
\hline $\mathrm{NO}_{x}-\mathrm{N}$ & oxidized nitrogen species $(\mathrm{mg} / \mathrm{l})$ \\
\hline OR & ozone reactor \\
\hline RI & raw (untreated) influent \\
\hline SB & sedimentation basin \\
\hline TAN & total ammonia nitrogen $(\mathrm{mg} / \mathrm{l})$ \\
\hline TF & trickling filter \\
\hline TKN & total Kjeldall nitrogen $(\mathrm{mg} / \mathrm{l})$ \\
\hline TSS & total suspended solids $(\mathrm{mg} / \mathrm{l})$ \\
\hline VSS & volatile suspended solids (mg/l) \\
\hline$Y_{\mathrm{b}}$ & biological (anoxic) yield (g microbial biomass produced/g substrate used) \\
\hline$Y_{\mathrm{NO}^{-}-\mathrm{N}}$ & biological yield for $\mathrm{NO}_{3}^{-}-\mathrm{N}$ (g biomass VSS/g NO${ }^{-}-\mathrm{N}$ ) \\
\hline$Y_{\mathrm{VSS}}$ & biological yield for VSS (g biomass VSS/g dissolved COD) \\
\hline$\underline{Y}_{\mathrm{COD}}$ & biological yield for COD ( $\mathrm{g}$ biomass COD/g dissolved COD) \\
\hline
\end{tabular}

Table 1. Nomenclature used in this chapter.

\section{Methods}

\subsection{Treatment train and experimental treatments}

The wastewater treatment train (Figure 1) included storage tanks, a primary sedimentation basin, mechanical filtration using a microscreen drum filter, denitrification using a fluidized bed biological reactor with methanol added to provide carbon and energy for cellular growth, ozonation and foam fractionation in a bubble-contact ozone reactor, dissolved ozone quenching in an air-bubble stripping chamber, aerobic biological treatment using a trickling filter, and jar test-scale chemical flocculation, followed by sand filtration. A detailed description of the pilot plant, its operation and analytical techniques may be found in Sandu (2004) or Sandu et al. (2008).

Our evaluation of pilot plant effectiveness consisted of four different experimental treatments (Table 2), differing by use of 6 or $4 \mathrm{lpm}$ flow and recycling rates, ozone doses between 36.6 - $82.5 \mathrm{mg} \mathrm{O}_{3} / 1$ water, and 6- or 9-minute ozonation times. 


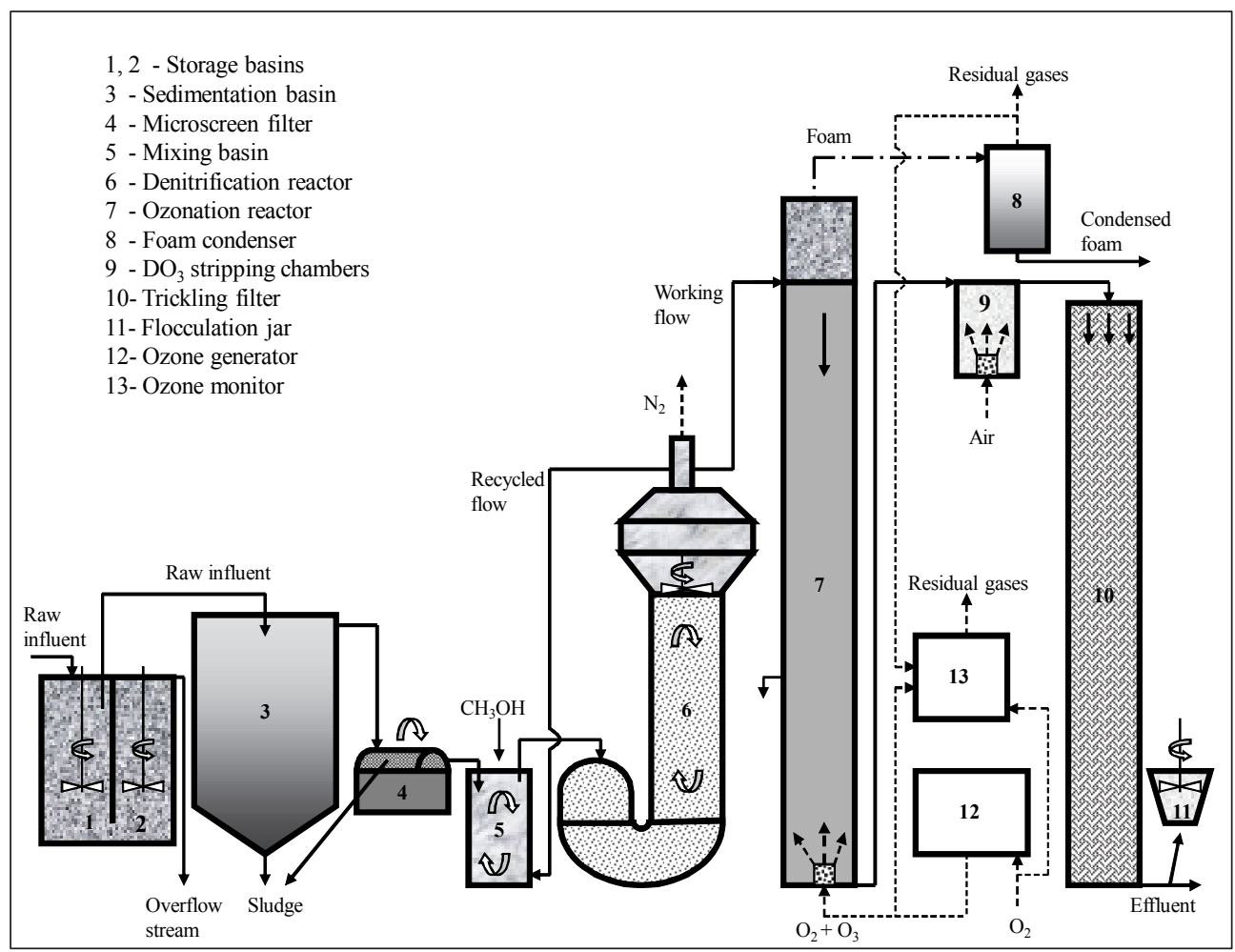

Fig. 1. Schematic diagram of pilot-scale wastewater treatment train at Blue Ridge Aquaculture. Details are not drawn to scale.

\begin{tabular}{|c|c|c|c|c|c|c|c|}
\hline \multirow{2}{*}{ Treatment } & \multirow{2}{*}{$\begin{array}{c}\text { Water } \\
\text { flow } \\
\text { lpm }\end{array}$} & \multirow{2}{*}{$\begin{array}{l}\text { Gas } \\
\text { flow }^{1} \\
\text { lpm }\end{array}$} & \multirow{2}{*}{$\begin{array}{c}\mathrm{O}_{3} \text { conc. } \\
\mathrm{mg} \mathrm{O}_{3} / 1 \text { gas }\end{array}$} & \multirow{2}{*}{$\begin{array}{l}\mathrm{O}_{3} \text { dose } \\
\mathrm{mg} \mathrm{O}_{3} / 1 \\
\text { water }\end{array}$} & \multicolumn{2}{|c|}{ Oz. time Recircul. DR ${ }^{2}$} & \multirow{2}{*}{$\begin{array}{c}\text { TF } \\
\text { used }^{3} \\
\%\end{array}$} \\
\hline & & & & & $\min$ & $\operatorname{lpm}(\%)$ & \\
\hline 1 & 6 & \multirow{4}{*}{10} & 22 & 36.6 & \multirow{2}{*}{6} & \multirow{2}{*}{$4(40 \%)$} & \multirow{2}{*}{100} \\
\hline 2 & \multirow{3}{*}{4} & & 33 & 55.0 & & & \\
\hline 3 & & & 33 & 82.5 & \multirow[b]{2}{*}{9} & \multirow{2}{*}{$6(60 \%)$} & \multirow{2}{*}{50} \\
\hline 4 & & & 22 & 55.0 & & & \\
\hline
\end{tabular}

1Flow of the $\mathrm{O}_{2} / \mathrm{O}_{3}$ mixture.

${ }^{2}$ Recirculation rate in the denitrification reactor.

3Proportion of cross section of trickling filter used.

Table 2. Controlled parameter conditions applied to the pilot station for the four experimental treatments. 


\subsection{Water quality assays}

Water samples collected for this study were passed through a $0.45 \mu \mathrm{m}$ filter and tested for total ammonia nitrogen (TAN), nitrate-nitrogen $\left(\mathrm{NO}_{3}^{-}-\mathrm{N}\right)$ and nitrite-nitrogen $\left(\mathrm{NO}_{2}-\mathrm{N}\right)$ content using a spectrophotometer (Hach DR 2400, Loveland, CO). Temperature and $\mathrm{pH}$ were determined by using a $\mathrm{pH} / \mathrm{mV} /{ }^{\circ} \mathrm{C}$ meter (Oakton ${ }^{\circledR}$ Acorn Meter Kit model $\mathrm{pH}$ 6, Vernon Hills, Illinois). Alkalinity and hardness were measured using Hach Permachem ${ }^{\circledR}$ Reagent methods. Total Kjeldall nitrogen (TKN) was determined by using macro-Kjeldall Standard Method 4500-Norg B, (American Public Health Association [APHA] et al., 1998).

For statistical analyses, 95\% simultaneous confidence intervals were determined to compare means of water quality parameters after passage through each of the five main units of the treatment train. We used a one-way ANOVA with the four treatments as the factor in the model; the values of the parameters in the influent water were added as covariates for ANOVAs performed for the sedimentation basin and the denitrification reactor. For the units following the denitrification reactor, covariates were not used because they did not improve the model.

\subsection{Biological yields determination}

The biological (anoxic) yield, $Y_{b}$ (i.e., the amount of microbial biomass formed per unit of substrate used), was determined using a bench-scale batch reactor for both methanol (as COD) and $\mathrm{NO}_{3}^{-}-\mathrm{N}$ substrates. The biomass produced was quantified as volatile suspended solids (VSS) and COD. A hermetically closed 5-L vessel was initially filled with water seeded with biofilm sheared from a sample of coated sand from the denitrification reactor. Potassium nitrate and methanol were added in amounts accounting for initial concentrations of $\mathrm{NO}_{3}^{-}-\mathrm{N}$ and methanol (as dissolved COD) of 207 and $1666 \mathrm{mg} / \mathrm{l}$, respectively. Methanol was well in excess of stoichiometric requirements so that it would not be a limiting factor. Continuous stirring and a constant temperature of $28 \pm 1^{\circ} \mathrm{C}$ were maintained. Pure nitrogen was injected for about 5 minutes to strip dissolved oxygen and to replace the air from the space above the fluid. Gas exiting at the top was collected and directed by a hose to a water bath, sealing the space. Any additional nitrogen gas produced by denitrification followed the same path before entering the atmosphere. The operation of purging nitrogen was repeated after any sample collection (i.e., at the beginning and at 12hour intervals through 48 hours). Total suspended solids (TSS), volatile suspended solids (VSS), dissolved and total chemical oxygen demand (COD) were measured according to Standard Methods 2540D, 2540E, and 5220C, respectively (APHA et al., 1998). $\mathrm{NO}_{3}^{-}-\mathrm{N}$ was determined spectrophotometrically (Hach DR 2400, Loveland, CO). Filters of 1.5- $\mu \mathrm{m}$ pore diameter were used for collecting TSS, and for obtaining samples for dissolved COD determinations. The equations used to determine $Y_{b}$ values (Grady et al., 1999) were:

$$
Y_{V S S}=\frac{\Delta V S S}{\Delta \text { dissolvedCOD }}\left(\frac{g}{g}\right)
$$

and:

$$
Y_{\mathrm{NO}_{3}}{ }^{-}-\mathrm{N}=\frac{\Delta V S S}{\Delta \mathrm{NO}_{3}{ }^{-}-\mathrm{N}}\left(\frac{g}{g}\right)
$$


$Y_{C O D}$ was obtained by the equation:

$$
Y_{C O D}=1.42 \times Y_{V S S}\left(\frac{g}{g}\right)
$$

Additionally, $Y_{\text {NO3- }} \mathrm{N}$ was determined from data collected from the denitrification reactor using Equation 2.

\section{Results and discussion}

\subsection{BRA waste stream characterization}

Characteristics of BRA aquaculture effluent regarding alkalinity, $\mathrm{pH}$, hardness, and nitrogenous compounds are presented in Table 3.

\begin{tabular}{lccc}
\hline Parameter & Average $^{1}$ & Minimum & Maximum \\
Alkalinity (mg/l) & 118 & 76 & 141 \\
Hardness (mg/l) & 150 & 139 & 170 \\
$\mathrm{pH}$ & 7.21 & 6.95 & 7.62 \\
$\mathrm{TKN}(\mathrm{mg} / \mathrm{l})$ & 31.5 & 5.11 & 47.36 \\
$\mathrm{TAN}(\mathrm{mg} / \mathrm{l})$ & 2.55 & 1.72 & 4.11 \\
$\mathrm{NO}_{3}^{--\mathrm{N}}(\mathrm{mg} / \mathrm{l})$ & 42.98 & 6.8 & 68.8 \\
$\mathrm{NO}_{2}-\mathrm{N}(\mathrm{mg} / \mathrm{l})$ & 0.91 & 0.45 & 1.93 \\
$\mathrm{TAN}(\mathrm{mg} / \mathrm{l})$ & 2.55 & 1.72 & 4.11 \\
\hline
\end{tabular}

${ }^{1}$ Average values represent non-flow-weighted averages (12\% for samples from 2:00 p.m. and $44 \%$ each for the other times).

Table 3. Waste stream characteristics for BRA effluent collected on different days at 6:00 a.m., 2:00 p.m. and 10:00 p.m. each day.

\subsection{Alkalinity}

Alkalinity is managed at BRA by addition of industrial-grade sodium bicarbonate, $\mathrm{NaHCO}_{3}$, which buffers $\mathrm{pH}$ and replaces alkalinity lost by nitrification and water exchange. Data from operation of the pilot station (Table 4) showed that alkalinity lost by water exchange was recovered and, further, that treated effluent was enriched by up to one-third of the initial amount of alkalinity. Alkalinity was generated in the denitrification reactor, increasing by approximately $40 \%$ in all experimental treatments. Despite the significant increase in percentage terms, the net production represented only about $2 \mathrm{mg}$ alkalinity per $\mathrm{mg}$ of $\mathrm{NO}_{3}{ }^{-}$ $-\mathrm{N}$ reduced. Because the stoichiometry of denitrification reactions would lead us to expect a ratio of about 3.6, we infer that some $\mathrm{NO}_{3}{ }^{-} \mathrm{N}$ must have been transformed into ammonia by assimilative reduction and used in cell synthesis when ammonia was lacking (Grady et al. 1999). The inference was supported by the observation that the wastewater treated was low in TAN, with a ratio of TAN: $\mathrm{NO}_{3}^{-}-\mathrm{N}$ of about 1:20.

The stream entering the ozonation reactor had an alkalinity of 175.5-187.5 mg/l. During ozonation, between $6-12 \%$ of alkalinity was lost. Loss of alkalinity could be due to the 


\begin{tabular}{|c|c|c|c|c|c|}
\hline \multirow{2}{*}{ Treatment } & SB & DR & OR & $\mathrm{TF}$ & Total increase ${ }^{2}$ \\
\hline & $\mathrm{mg} / 1$ & $\mathrm{mg} / \mathrm{l} \quad(\%)$ & $\mathrm{mg} / 1 \quad(\%)$ & $\mathrm{mg} / 1 \quad(\%)$ & $(\%)$ \\
\hline 1 & 1145 & $1921(+404) a$ & $175.5(-6.6)^{a}$ & $163.6(-6.8)^{a}$ & $30.0^{\mathrm{a}}$ \\
\hline 2 & 114.3 & $192.1(+40.4)^{a}$ & $179.9(-6.4)^{\mathrm{a}}$ & $169.3(-5.9)^{a}$ & $32.4^{\mathrm{a}}$ \\
\hline 3 & 1217 & 201 & $187.5(-7.1)^{a}$ & $179.5(-4.2)^{\mathrm{a}}$ & $32.2^{\mathrm{a}}$ \\
\hline 4 & 121.7 & $201.8(+39.1)^{\mathrm{a}}$ & $177.8(-11.9)^{\mathrm{a}}$ & $164.3(-7.5)^{\mathrm{a}}$ & $26.0^{\mathrm{a}}$ \\
\hline
\end{tabular}

${ }^{1}$ Abbreviations: $\mathrm{SB}=$ sedimentation basin, $\mathrm{DR}=$ denitrification reactor, $\mathrm{OR}=$ ozonation reactor, and $\mathrm{TF}$ $=$ trickling filter.

${ }^{2}$ Alkalinity increase between sedimentation basin and trickling filter effluent concentrations.

Table 4. Dynamics of alkalinity through the pilot plant for all treatments (unit outlet values) ${ }^{1}$. Means in a column with the same superscript are not significantly different $(p>0.05)$.

scavenging effect of its ions on ozone. $\mathrm{HCO}_{3}^{-}$and $\mathrm{CO}_{3}{ }^{2-}$ ions compete in wastewater with organic matter for reaction with the $\mathrm{OH}^{\circ}$ radical, and high alkalinity can impair the reaction of ozone with targeted organics (Wang \& Pai 2001); alkalinity depletion increases with ozone dose due to increased probability of $\mathrm{OH}^{\circ}$ radical formation due to faster organics removal. The relatively low removal of alkalinity that we observed may have been limited by the $\mathrm{pH}$ of slightly over 8.0, not high enough for carbonate ion formation, and with ozone being less reactive with bicarbonate ion. Buxton et al. (1988) found the reaction rate constants for reaction of hydroxyl ion to be $39 \times 10^{7} \mathrm{l} / \mathrm{mol}-\mathrm{s}$ for $\mathrm{CO}_{3}^{-2}$ ions and $0.85 \times 10^{7} \mathrm{l} / \mathrm{mol}-$ s for $\mathrm{HCO}_{3}$.

More alkalinity was removed in the tricking filter, probably due to nitrification. This observation was not surprising, because stoichiometrically $1 \mathrm{~g}$ of TAN can destroy $8.62 \mathrm{~g}$ of $\mathrm{HCO}_{3}{ }^{-}$during oxidation to $\mathrm{NO}_{3}^{--N}$ (Grady et al., 1999). However, because TAN concentration was relatively low and because the nitrification was not complete (i.e., $\mathrm{NO}_{2}-\mathrm{N}$ was produced in the biofilter), the final effluent still had $26.0-32.6 \%$ more alkalinity than the stream entering the wastewater treatment train. Hence, reuse of this treated effluent could result in savings regarding supplemental alkalinity addition to the aquaculture system.

\section{$3.3 \mathrm{pH}$}

The $\mathrm{pH}$ of the aquaculture effluent was neutral or slightly basic (Table 5), close to that of water in the fish production tanks. Neutral $\mathrm{pH}$ in wastewater can be due to the presence of inorganic salts (Millamena 1992) or to the heterogeneous composition of its organic matter (Medley \& Stover 1983); BRA effluent exhibited both of these characteristics. After entering the treatment train, $\mathrm{pH}$ increased slightly in the storage tanks and settling basin, and then increased more significantly during denitrification, reaching values between 8.22 and 8.26 in denitrification reactor effluent. The $\mathrm{pH}$ increase was probably due to intense biological activity in these units, especially in the denitrification reactor, where $\mathrm{pH}$ increase was promoted by alkalinity generation. During ozonation, $\mathrm{pH}$ decreased, probably because some alkalinity was lost to attack by ozone-derived radicals. Kirk et al. (1975) found that whether ozonation feed water is acidic or basic, the product water always shifts toward neutrality, and that the $\mathrm{pH}$ change is greater for higher-COD feedwaters. Further, Wang \& Pai (2001) suggested that the greatest organics removal by ozonation is obtained at low $\mathrm{pH}$, 


\begin{tabular}{ccccccc}
\hline Treatment & RI & SB & DR & OR & TF & CF \\
\hline 1 & 7.22 & $7.30^{\mathrm{a}}$ & $8.26^{\mathrm{a}}$ & $8.09^{\mathrm{a}}$ & $8.32^{\mathrm{a}}$ & $7.61^{\mathrm{a}}$ \\
2 & & & & $7.89^{\mathrm{a}}$ & $8.24^{\mathrm{a}}$ & $7.63^{\mathrm{a}}$ \\
3 & \multirow{2}{*}{7.20} & $7.37^{\mathrm{a}}$ & $8.22^{\mathrm{a}}$ & $7.89^{\mathrm{a}}$ & $8.22^{\mathrm{a}}$ & $7.58^{\mathrm{a}}$ \\
\hline
\end{tabular}

1 Abbreviations: $\mathrm{RI}=$ raw influent, $\mathrm{SB}=$ sedimentation basin, $\mathrm{DR}=$ denitrification reactor, $\mathrm{OR}=$ ozonation reactor, $\mathrm{TF}=$ trickling filter, and $\mathrm{CF}=$ chemical flocculation .

Table 5. Dynamics of $\mathrm{pH}$ values through the treatment train ${ }^{1}$ for all experimental treatments (unit outlet values). Means in a column with the same superscript are not significantly different $(p>0.05)$.

suggesting that the relatively high-pH water in our study could be disadvantageous. $\mathrm{pH}$ increased again in the trickling filter, which was somewhat surprising considering that nitrification occurred in this filter and some alkalinity was lost. The effects of large amounts of organics in the influent and their compositional diversity may have overshadowed the effects of nitrification of relatively small amounts of ammonia. Additionally, $\mathrm{CO}_{2}$ stripping could have contributed to $\mathrm{pH}$ increase.

Further decline of $\mathrm{pH}$ occurred during chemical flocculation, reaching final values of about 7.60 , which is considered safe for fish production.

\subsection{Hardness}

Hardness enters the BRA systems with replacement spring water and with feed, and supports biomass development for both fish and for microorganisms in biofilters. Average hardness concentrations were between 148.4 and $151.5 \mathrm{mg} / 1$ as $\mathrm{CaCO}_{3}$, characterizing BRA effluent as a medium-hard wastewater. Table 6 presents the dynamics of hardness as the water passed through the treatment station.

\begin{tabular}{|c|c|c|c|c|c|c|}
\hline \multirow{2}{*}{ Treatment } & \multicolumn{2}{|l|}{ SB } & OR & \multicolumn{2}{|l|}{ TF } & \multirow{2}{*}{$\begin{array}{l}\text { Total decrease } 2 \\
(\%)\end{array}$} \\
\hline & $\mathrm{mg} / \mathrm{l}$ & $\mathrm{mg} / \mathrm{l} \quad(\%)$ & $\mathrm{mg} / \mathrm{l} \quad(\%)$ & $\mathrm{mg} / \mathrm{l}$ & $(\%)$ & \\
\hline 1 & $1515^{\mathrm{a}}$ & $145.7(3.8)^{a}$ & $139.7(4.1)^{\mathrm{a}}$ & 138.0 & $(1.2)^{\mathrm{a}}$ & $8.9^{a}$ \\
\hline 2 & & & $137.4(5.7)^{\mathrm{b}}$ & 135.9 & $(1.1)^{\mathrm{a}}$ & $10.3^{a}$ \\
\hline 3 & $148.4^{a}$ & $141.7(4.5)^{\mathrm{a}}$ & $130.6(7.8)^{\mathrm{ab}}$ & 129.5 & $(0.8)^{\mathrm{a}}$ & $12.7 \mathrm{a}$ \\
\hline 4 & & & $134.6(5.0)^{\mathrm{ab}}$ & 132.6 & $(1.5)^{\mathrm{a}}$ & $10.6^{\mathrm{a}}$ \\
\hline
\end{tabular}

${ }^{1}$ Abbreviations: $\mathrm{SB}=$ sedimentation basin, $\mathrm{DR}=$ denitrification reactor, $\mathrm{OR}=$ ozonation reactor, and $\mathrm{TF}=$ trickling filter.

${ }^{2}$ Hardness decrease between settling basin and trickling filter effluent concentrations.

Table 6. Dynamics of hardness through the pilot plant ${ }^{1}$ for all experimental treatments (unit outlet values). Means in a column with the same superscript are not significantly different $(p>0.05)$. 
Small amounts of hardness were lost between the settling basin and denitrification reactor effluents, suggesting that it was removed by microscreen filtration after bonding with dissolved and colloidal organics, or was assimilated during bacterial growth in the denitrification reactor.

Hardness decreased further during ozonation, with the decrease proportional to the amount of ozone applied (e.g., 4.1\% removal in Treatment 1 and $7.8 \%$ removal in Treatment 3, a statistically significant difference). Ozone-induced hardness removal was probably because increased carboxyl acid concentration due to ozonation led to greater magnesium and calcium association, resulting in precipitation of metal-humate complexes (Grasso \& Weber 1988). Higher hardness removal at higher ozone doses was attributable to more destabilized carboxyl acids binding with a larger amount of hardness ion species. Noting that increasing hardness to $150 \mathrm{mg} / \mathrm{L} \mathrm{CaCO}_{3}$ in ozonated water improved removal of TSS (Rueter \& Johnson 1995), BRA effluent exhibited favorable conditions for TSS removal. After being formed in the aqueous medium, TSS complexes likely were caught on bubble surfaces and buoyed to the top as foam, explaining the high TSS removal efficiency during ozonation (Sandu et al. 2008). Once in the foam, however, the association of hardness with TSS seems to have been attacked by ozone, which broke and dissolved TSS particles.

Small amounts of hardness were lost in the trickling filter, probably due to bacterial assimilation and bonding into solids.

Although hardness was not greatly reduced during treatment, it could become depleted below critical limits after repeated treatments, and hence may require periodic adjustment.

\subsection{TKN}

In raw influent, TKN ranged between $41.8-42.3 \mathrm{mg} / \mathrm{l}$, mostly as organic nitrogen. Table 7 shows TKN dynamics through the entire treatment train. TKN was removed in approximately the same proportion as COD during sedimentation, indicating that nitrogencontaining organics were distributed similarly between solid and dissolved forms. A slight decrease in TKN was observed in the denitrification reactor, which could be attributed to ammonia consumption in this reactor.

\begin{tabular}{|c|c|c|c|c|c|}
\hline \multirow{2}{*}{ Treatment } & RI & SB & OR & $\mathrm{CF}$ & \multirow{2}{*}{$\frac{\text { Total removal }^{2}}{(\%)}$} \\
\hline & $\mathrm{mg} / \mathrm{l}$ & $\mathrm{mg} / \mathrm{l} \quad(\%)$ & $\mathrm{mg} / 1 \quad(\%)$ & $\mathrm{mg} / \mathrm{l} \quad(\%)$ & \\
\hline 1 & 418 & & $9.2 \quad(45.6)^{\mathrm{a}}$ & $2.0 \quad(78.7)^{\mathrm{a}}$ & $95.2^{a}$ \\
\hline 2 & 41.8 & ) & $8.2 \quad(51.5)^{a b}$ & $1.9 \quad(76.8)^{\mathrm{a}}$ & $95.5^{\mathrm{a}}$ \\
\hline 3 & 122 & $160 \quad(617)$ & $7.4(54.3)^{b}$ & $1.7 \quad(77.0)^{\mathrm{a}}$ & $96.0^{\mathrm{a}}$ \\
\hline 4 & 42.3 & (01.7) & $8.2(49.4)^{\mathrm{ab}}$ & $1.9 \quad(76.8)^{\mathrm{a}}$ & $95.5^{\mathrm{a}}$ \\
\hline
\end{tabular}

${ }^{1}$ Abbreviations: $\mathrm{RI}=$ raw influent, $\mathrm{SB}=$ sedimentation basin, $\mathrm{OR}=$ ozonation reactor, and $\mathrm{CF}=$ chemical flocculation.

${ }^{2}$ Decline of TKN between raw influent and trickling filter effluent concentrations.

Table 7. Total Kjeldall nitrogen (TKN) dynamics through the pilot plant ${ }^{1}$ for each treatment (unit outlet values). Means in a column with the same superscript are not significantly different $(p>0.05)$. 
Ozonation removed up to $54 \%$ of influent TKN (at the highest ozone dose), which exceeded the proportion of COD removal. There was a statistically significant difference in TKN removal between Treatments 1 and 3, suggesting that TKN removal rate depended on ozone dose. Nitrogen-containing compounds are more prone to ozone-mediated destabilization than many other organics, facilitating bonding with opposite electrical charges (Razumovskii \& Zaikov, 1984). In this case, N-containing compounds likely bonded directly to charges at the surface of gas bubbles (fractionation effect) or with polyvalent ions, and subsequently were removed with foam. Some of these molecules also were mineralized, which is reflected in the ammonia increase during ozonation. In turn, $\mathrm{NO}_{3}^{-}-\mathrm{N}$ rose slightly during ozonation as some ammonia was oxidized further due to favorable conditions in an alkaline environment and $\mathrm{pH}$ above 8 (Lin \& Wu 1996). Our results showed a generally higher TKN removal than other studies. For example, Beltran et al. (2001) found a $26 \%$ TKN removal at ozone doses between $40-60 \mathrm{mg} / \mathrm{l}$ on domestic wastewater that had been treated biologically. Higher TKN removal in our study could be attributed to higher alkalinity in BRA wastewater and to different composition of organics in the two wastewaters.

In the trickling filter, TKN was reduced by $15-31 \%$. The percent removal did not appear to depend on the ozone dose applied in the previous treatment step. Although an increase in ozone dose should promote TKN removal (Beltran et al. 2001), our finding differed, probably because a great part of TKN was in the form of ammonia after ozonation. In this circumstance, TKN removal efficiency was rather dependent on the nitrification performance of the trickling filter.

TKN removal by chemical flocculation ranged from $77-79 \%$. Comparing the average of 1.7-2.0 $\mathrm{mg} / 1$ for TKN after chemical flocculation to an average of $1.5-1.7 \mathrm{mg} / \mathrm{l}$ for TAN, it is clear that the organic component of TKN was almost entirely removed by the treatment train.

\subsection{TAN}

Table 8 shows TAN dynamics through the treatment train. The average influent TAN concentration ranged between 2.53 and $2.58 \mathrm{mg} / 1$ in all experimental treatments. These values were higher than the average of $2.06 \mathrm{mg} / 1$ in the recirculating aquaculture systems, with the increase likely due to bacterial activity in the storage tanks and sedimentation basin. Ammonia is utilized preferentially as a nitrogen source by heterotrophic bacteria (Grady et al. 1999), explaining the $48-50 \%$ reduction of TAN as the stream underwent denitrification.

During ozonation, TAN concentration rose higher than influent levels by a treatment average of $29-40 \%$. These TAN concentrations were over twice those in the denitrification reactor effluent in Treatments 2 and 3. The increase of TAN concentration during ozonation exhibited a positive, linear relationship with ozone dose (slope $=0.012 ; r^{2}=0.93$ ). The increase of TAN probably was due to amino acid and protein oxidation by ozone. Ammonia is a byproduct of these reactions, especially when they are complete (i.e., mineralization). The basic $\mathrm{pH}$ of the ozonation reactor influent appeared to promote partial oxidation of ammonia to nitrate, because $\mathrm{NO}_{3}^{-}-\mathrm{N}$ increased by more than expected from influent $\mathrm{NO}_{2}-\mathrm{N}$ oxidation. However, the oxidation reaction was insignificant and ammonia accumulation predominated. Rosenthal \& Otte (1979) and Wang \& Pai (2001) also reported partial oxidation of ammonia to $\mathrm{NO}_{3}-\mathrm{N}$ during ozonation under alkaline conditions, with TAN accumulating via oxidation of organic nitrogen. 


\begin{tabular}{|c|c|c|c|c|c|c|}
\hline \multirow{2}{*}{ Treatment } & SB & DR & OR & OR \% & $\mathrm{TF}$ & \multirow{2}{*}{$\begin{array}{c}\text { Total }^{3} \\
(\%)\end{array}$} \\
\hline & $\mathrm{mg} / 1$ & mg/1 (\%) & $\mathrm{mg} / \mathrm{l}$ & Increase $^{2}$ & $\mathrm{mg} / 1 \quad(\%)$ & \\
\hline 1 & \multirow{2}{*}{2.58} & \multirow{2}{*}{$1.33(-48.4)^{\mathrm{a}}$} & $3.64(+173.6)^{\mathrm{a}}$ & 29.1 & $1.69(-53.6)^{\mathrm{a}}$ & $34.5^{\mathrm{a}}$ \\
\hline 2 & & & $3.92(+194.7)^{\mathrm{a}}$ & 34.2 & $1.59(-59.4)^{\mathrm{a}}$ & $38.4^{\mathrm{a}}$ \\
\hline 3 & \multirow{2}{*}{2.53} & \multirow{2}{*}{$1.26(-50.2)^{a}$} & $4.21(+234.1)^{\mathrm{a}}$ & 39.9 & $1.52(-63.9)^{\mathrm{a}}$ & $39.9^{a}$ \\
\hline 4 & & & $4.00(+217.5)^{\mathrm{a}}$ & 36.8 & $1.63(-59.3)^{\mathrm{a}}$ & $35.6^{\mathrm{a}}$ \\
\hline
\end{tabular}

${ }^{1}$ Abbreviations: $\mathrm{SB}=$ sedimentation basin, $\mathrm{TF}=$ trickling filter, $\mathrm{OR}=$ ozonation reactor, and $\mathrm{DR}=$ denitrification reactor.

2Percent increase of TAN concentration after ozonation from the initial TAN concentration in the sedimentation basin.

3Percent decrease of TAN concentration after ozonation from the initial TAN concentration in the sedimentation basin.

Table 8. Total ammonia nitrogen (TAN) dynamics through the pilot plant ${ }^{1}$ for all treatments (unit outlet values). Means in a column with the same superscript are not significantly different $(p>0.05)$.

In the trickling filter, partial nitrification occurred, removing 54-64\% of TAN along with organics. The organic loading of the trickling filter was estimated at $0.43 \mathrm{~kg} \mathrm{cBOD} 5 / \mathrm{m}^{3}-\mathrm{d}$ in treatments 1 and 2, and $0.65 \mathrm{~kg} \mathrm{cBOD} 5 / \mathrm{m}^{3}$-day in Treatments 3 and 4 . At these loadings, conditions were not permissive for nitrifiers to grow and compete effectively with heterotrophs, which made the nitrification performance of the trickling filter surprisingly good. In comparison, Metcalf \& Eddy (1979, as cited in Karnchanawong and Polprasert, 1990) obtained $75-85 \%$ TAN removal in a trickling filter at lower volumetric loadings of 0.10 to $0.16 \mathrm{~kg} \mathrm{BOD} 5 / \mathrm{m}^{3}$-day. Parker \& Richards (1986) suggested a maximum threshold of 27 $\mathrm{mg} / 1 \mathrm{BOD}_{5}$ in order for any nitrification to occur in a trickling filter. Our results also showed more efficient TAN removal when the stream had less organics, as in Treatment 3 , although we measured $\mathrm{CBOD}_{5}$ instead of soluble $\mathrm{BOD}_{5}$.

The final effluent had TAN treatment averages between 1.52 and $1.69 \mathrm{mg} / \mathrm{l}$, which is generally undesirable in water used for exchange in aquaculture systems. However, were this treated water used for exchange, only $0.84 \%$ of daily TAN production would be reintroduced and the rotating biological contactors in the fish production systems would be able to remove these amounts (Sandu et al. 2008).

\section{$3.7 \mathrm{NO}_{2}-\mathrm{N}$}

Nitrite results from incomplete nitrification in the aquaculture systems' rotating biological contactors. The average concentration was between 0.92 and $0.96 \mathrm{mg} / 1 \mathrm{NO}_{2}^{--} \mathrm{N}$ in $\mathrm{BRA}$ effluent. $\mathrm{NO}_{2}-\mathrm{N}$ concentration fluctuated through the treatment train (Table 9).

In the denitrification reactor, between $72-76 \%$ of influent $\mathrm{NO}_{2}-\mathrm{N}$ was reduced to nitrogen. This reduction suggests that the external carbon source was supplied in an amount sufficient to support the completion of denitrification (van Rijn \& Rivera 1990) and that influent nitrite also was reduced in this process. Another mechanism for nitrite reduction could be its utilization as a source of nitrogen by heterotrophic organisms in the upper part of the biofilter due to the relatively low concentration of TAN in the stream. While we cannot conclude which of these factors drove it, we regard $\mathrm{NO}_{2}-\mathrm{N}$ reduction in the 


\begin{tabular}{|c|c|c|c|c|c|c|}
\hline \multirow{2}{*}{ Treatment } & \multirow{2}{*}{$\frac{\mathrm{SB}}{\mathrm{mg} / \mathrm{l}}$} & DR & OR & \multicolumn{2}{|c|}{$\mathrm{TF}$} & \multirow{2}{*}{$\begin{array}{c}\text { Total removal } \\
(\%)\end{array}$} \\
\hline & & $\mathrm{mg} / 1 \quad(\%)$ & $\mathrm{mg} / 1 \quad(\%)$ & $\mathrm{mg} / \mathrm{l}$ & $(\%)^{2}$ & \\
\hline 1 & \multirow{2}{*}{0.96} & \multirow{2}{*}{$0.23(76.0)$} & \multirow{2}{*}{$0.00(24.0)$} & 0.45 & $(+55.6)^{a}$ & $44.4^{\mathrm{a}}$ \\
\hline 2 & & & & 0.54 & $(+52.9)^{\mathrm{a}}$ & $47.1^{\mathrm{a}}$ \\
\hline 3 & \multirow{2}{*}{0.92} & \multirow{2}{*}{$0.26(71.7)$} & \multirow{2}{*}{$0.00(28.3)$} & 0.61 & $(+58.7)^{\mathrm{a}}$ & $41.3^{a}$ \\
\hline 4 & & & & 0.51 & $(+63.8)^{\mathrm{a}}$ & $36.2^{a}$ \\
\hline
\end{tabular}

${ }^{1}$ Abbreviations: $\mathrm{SB}=$ sedimentation basin, $\mathrm{TF}=$ trickling filter, $\mathrm{DR}=$ denitrification reactor, and $\mathrm{OR}=$ ozonation reactor.

${ }^{2}$ Percentages for the trickling filter express the mass generated as a fraction of the treatment train influent concentrations.

${ }^{3}$ Total percent decrease of $\mathrm{NO}_{2}-\mathrm{N}$ concentration relative to initial TAN concentration in the sedimentation basin.

Table 9. Nitrite-nitrogen $\left(\mathrm{NO}_{2}-\mathrm{N}\right)$ dynamics through the pilot plant ${ }^{1}$ for all treatments (unit outlet values). Means in a column with the same superscript are not significantly different $(p>0.05)$.

denitrification reactor as a positive outcome from application of excess methanol. Although the excess methanol could impose a higher dissolved organics load on the ozone reactor, this outcome may be preferred to poorer removal of nitrogenous compounds.

The remaining $\mathrm{NO}_{2}^{--} \mathrm{N}$ then was oxidized totally to $\mathrm{NO}_{3}^{-}-\mathrm{N}$ in the ozone reactor, regardless of the ozone dose applied. Rosenthal \& Otte (1979) also found that even with light ozonation, $\mathrm{NO}_{2}^{--} \mathrm{N}$ in aquaculture wastewaters can be oxidized efficiently to $\mathrm{NO}_{3}^{-}-\mathrm{N}$.

Although the stream entering the trickling filter had little or no $\mathrm{NO}_{2}^{--} \mathrm{N}$, the effluent had an average of $0.45-0.61 \mathrm{mg} / 1 \mathrm{NO}_{2}-\mathrm{N}$, varying among experimental treatments. This concentration represented $53-64 \%$ of the treatment train influent concentration. The generation of $\mathrm{NO}_{2}-\mathrm{N}$ in the trickling filter probably was due to incomplete nitrification of ammonia. One of the causes could be the lack of $\mathrm{NO}_{2}-\mathrm{N}$ itself as substrate in the influent, which did not support the growth of bacteria converting $\mathrm{NO}_{2}-\mathrm{N}$ to $\mathrm{NO}_{3}^{--} \mathrm{N}$ (i.e., Nitrobacter sp.). Summerfelt (2003) suggested that lack of these species in nitrification biofilters can be a drawback of integrating an ozonation step in a treatment loop in a recirculating aquaculture system, although the decrease of nitrite levels is a substantial benefit. Another cause of nitrite generation could be suppressed growth of Nitrobacter $s p$. by faster-growing heterotrophs under conditions of abundant of organic material (Parker \& Richards 1986). Nitrobacter sp. are the slowest-growing nitrifiers and are the first to be eliminated by heterotrophs in a biofilter when competing for space (Grady et al. 1999). Considering nitrite and organic concentrations coming into the trickling filter in our study, both mechanisms appear plausible explanations for nitrite accumulation.

The presence of nitrite is undesirable in waters used for exchange in recirculating aquaculture systems because of its toxicity to fish, although the concentrations in our final effluent did not present a threat to fish. Further, the rotating biological contactors in the BRA fish production systems would be able to remove the amounts of $\mathrm{NO}_{2}-\mathrm{N}$ returned with exchange water. 


\section{$3.8 \mathrm{NO}_{3}-\mathrm{N}$}

Nitrate was the most abundant nitrogenous waster in BRA effluent, resulting from nitrification and accumulation in the system. Treatment averages were between 42.8 and $43.2 \mathrm{mg} / 1 \mathrm{NO}_{3}-\mathrm{N}$ in the influent (Table 10), although large diurnal variations were observed due to different representations of wastewaters from greenhouses and grow-out systems within the overall BRA operation. On average, the denitrification reactor removed $96-97 \%$ of $\mathrm{NO}_{3}-\mathrm{N}$ among experimental treatments, suggesting that the biofilter adapted rapidly to nitrate fluctuations. This observation agrees with Jeris \& Owens' (1975) suggestion that under conditions of nitrate variation, it is sufficient to supply the right amount of carbon source at any time in order to obtain satisfactory denitrification. Nitrate removal performance appeared to be independent of the recycled stream fraction among different treatments.

\begin{tabular}{ccccc}
\hline \multirow{2}{*}{ Treatment } & $\mathrm{SB}$ & $\mathrm{DR}$ & $\mathrm{TF}$ & Total removal $^{2}$ \\
\cline { 2 - 5 } & $\mathrm{mg} / \mathrm{l}$ & $\mathrm{mg} / \mathrm{l}(\%)$ & $\mathrm{mg} / \mathrm{l}$ & $(\%)$ \\
\hline 1 & \multirow{2}{*}{43.2} & \multirow{2}{*}{$1.8(95.8)^{\mathrm{a}}$} & $2.6^{\mathrm{a}}$ & 94.0 \\
2 & & & $2.7^{\mathrm{a}}$ & 93.8 \\
3 & \multirow{2}{*}{$1.3(97.0)^{\mathrm{a}}$} & $2.0^{\mathrm{a}}$ & 95.4 \\
4 & \multirow{2}{*}{42.8} & & $2.4^{\mathrm{a}}$ & 94.4 \\
\hline
\end{tabular}

\footnotetext{
${ }^{1}$ Abbreviations: $\mathrm{SB}=$ sedimentation basin, $\mathrm{TF}=$ trickling filter, and $\mathrm{DR}=$ denitrification reactor. ${ }^{2}$ Total percent decrease of $\mathrm{NO}_{3}-\mathrm{N}$ concentration relative to initial TAN concentration in the sedimentation basin.
}

Table 10. Nitrate-nitrogen $\left(\mathrm{NO}_{3}-\mathrm{N}\right)$ dynamics through the pilot plant ${ }^{1}$ for all treatments (unit outlet values). Means in a column with the same superscript are not significantly different $(p>0.05)$.

The nitrate removal efficiency of the treatment train overall was slightly lower than that of the denitrification reactor unit, as $\mathrm{NO}_{3}^{-}-\mathrm{N}$ was produced during ozonation and by nitrification in the trickling filter. However, the final concentration was generally less than 3 $\mathrm{mg} / \mathrm{l}$, posing no issue for reuse of the recovered wastewater for fish production.

\subsection{Cell yields and the effect of nitrate fed on denitrification}

From tests on the batch reactor, cell yield, $Y_{\mathrm{NO}_{3}-\mathrm{N}}$, was $0.69 \mathrm{~g}$ VSS cells produced/g $\mathrm{NO}_{3}-\mathrm{N}$ consumed. Our $Y_{b}$ value agrees with those reported from tests with similar $\mathrm{NO}_{3}^{--\mathrm{N}}$ concentrations (Table 11). However, Moore \& Schroeder (1971) showed that under steady-

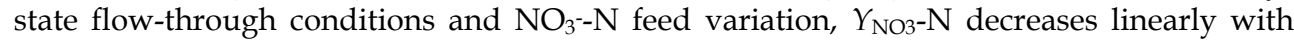
increasing $\mathrm{NO}_{3}^{--} \mathrm{N}$ concentration to about $35 \mathrm{mg} / 1 \mathrm{NO}_{3}^{-}-\mathrm{N}$, and remains constant thereafter. They attributed this relationship to a saturation effect, because some species of bacteria synthesize polysaccharide storage materials under nitrogen-limited conditions. Consequently, the process slows as more $\mathrm{NO}_{3}-\mathrm{N}$ is utilized, resulting in $Y_{\text {NO3-N }}$ decreasing until $\mathrm{NO}_{3}-\mathrm{N}$ reaches the saturation level. Above $35 \mathrm{mg} / 1 \mathrm{NO}_{3}^{--} \mathrm{N}, Y_{\mathrm{NO}-\mathrm{N}}$ was found to be around $0.60 \mathrm{~g}$ VSS cells produced/g $\mathrm{NO}_{3}{ }^{-} \mathrm{N}$ consumed (Moore \& Schroeder, 1971), which is similar to the value we found. Hence, we infer that tests in our study were conducted under saturation conditions. Indeed, batch tests started from a $\mathrm{NO}_{3}{ }^{-}-\mathrm{N}$ concentration of $207 \mathrm{mg} / \mathrm{l}$, and were interrupted close to the putative saturation limit. 


\begin{tabular}{lccc}
\hline \multicolumn{1}{c}{ Source } & $\begin{array}{c}Y \text { (Biomass VSS/ } \\
\left.\mathrm{NO}^{-}-\mathrm{N}\right)\end{array}$ & $\begin{array}{c}Y \text { (Biomass VSS/ } \\
\text { Dissolved COD })\end{array}$ & $\begin{array}{c}Y \text { (Biomass COD/ } \\
\text { Dissolved COD) }\end{array}$ \\
\hline This study & 0.69 & 0.29 & 0.41 \\
Semon et al. (1997) & 0.62 & $0.17-0.18$ & $0.24-0.26$ \\
Jeris et al. (1977) & 0.57 & 0.17 & 0.24 \\
Moore \& Schroeder (1971) & $0.53-1.4$ & $0.14-0.29$ & $0.17-0.35$ \\
Coelhoso et al. (1992) & $0.5-1.3$ & - & - \\
Stephenson \& Murphy (1980) & 1.0 & - & - \\
Grady et al. (1999) & - & 0.27 & 0.39 \\
\hline
\end{tabular}

Table 11. Comparison of biological yield $\left(Y_{b}\right)$ estimates from this study (batch reactor tests) and from the literature under $\mathrm{NO}_{3}^{-}-\mathrm{N}$ saturation conditions.

$Y_{\text {VSS }}$ and $Y_{\text {COD }}$ were determined to have values of 0.29 and $0.41 \mathrm{~g} / \mathrm{g}$, respectively. These values agree only with those reported by Grady et al. (1999), and are larger than values reported by other authors (Table 11). For example, Jeris \& Owens (1975) suggested that between 15 and $20 \%$ of the methanol consumed is expected to be converted into cell mass, while Karnchanawong \& Polprasert (1990) found this conversion to be between 20 and 28\%. The difference could be explained by noting that Grady et al.'s (1999) values were obtained under conditions similar to those in this study, such as excess $\mathrm{NO}_{3}-\mathrm{N}$, and continuouslystirred, batch tank reactors. Such conditions exploited the maximum potential for ATP formation under anoxic conditions, resulting in a higher yield for anoxic growth. In contrast, other authors (Table 10) derived their results from steady-state operating conditions in fluidized bed biological reactors, which have much higher denitrification rates than continuously-stirred tank reactors. Lower denitrification rates coincide with high solids production rates (Stephenson \& Murphy, 1980), helping to explain the larger $Y_{\mathrm{VSS}}$ and $Y_{\mathrm{COD}}$ values observed in continuously-stirred tank reactor tests.

We also determined $Y_{\text {NO3-N }}$ using denitrification reactor data in order to confirm the results and interpretations above, and also to characterize the behavior of the denitrification reactor under conditions of diurnal $\mathrm{NO}_{3}-\mathrm{N}$ variations. Our findings (Table 12) confirmed that the denitrification reactor worked at an $\mathrm{NO}_{3}^{-}-\mathrm{N}$ dose lower than saturation and resulted in a larger $Y_{\mathrm{NO} 3}-\mathrm{N}$. Additionally, the largest yields were obtained for the afternoon measurements, i.e., the lowest $\mathrm{NO}_{3}{ }^{-} \mathrm{N}$ influent, regardless of experimental treatment or working stream flow.

The weighted average biomass production for the denitrification reactor (as VSS) was estimated at $20.2 \mathrm{~kg} \mathrm{VSS} \mathrm{m} 3$ /day for the $6 \mathrm{Lpm}$ working flow rate, and $15.8 \mathrm{~kg} \mathrm{VSS} \mathrm{m}^{3} /$ day for $4 \mathrm{Lpm}$. The difference was probably due to the different percent of recirculation, which resulted in different working streams. As was suggested by the biofilter $Y_{\mathrm{NO}}-\mathrm{N}$ (i.e., approximately one), nitrogen removal values approximated those of VSS removal. Nitrogen removal was between $23.4 \mathrm{~kg} \mathrm{NO}_{3}^{--} \mathrm{N} \mathrm{m}^{3} /$ day for the $6 \mathrm{Lpm}$ working flow, and $16.2 \mathrm{~kg} \mathrm{NO}_{3}^{-}$ $-\mathrm{N} \mathrm{m}^{3}$ /day for $4 \mathrm{Lpm}$. Our maximum nitrogen removal was higher than generally expected from denitrification for domestic wastewater treatment. For example, Coelhoso et al. (1992) obtained nitrogen removal of 5.4 to $10.4 \mathrm{~kg} \mathrm{NO}_{3}-\mathrm{N} \mathrm{m}^{3} /$ day. Semon et al. (1997) suggested a maximum design loading of $6.4 \mathrm{~kg} \mathrm{NO}_{3}-\mathrm{N} \mathrm{m}^{3} /$ day. Jeris \& Owens (1975) reported nitrogen removal of $20.7 \mathrm{~kg} \mathrm{NO}_{3}-\mathrm{N} \mathrm{m}^{3} /$ day in fluidized sand biological reactors. The higher removal rate in our study was probably because of the higher operating temperature, which drove 


\begin{tabular}{|c|c|c|c|c|c|c|c|}
\hline \multirow{3}{*}{$\begin{array}{l}\text { Treatments } \\
\text { (Sampling time) }\end{array}$} & \multirow{3}{*}{$\begin{array}{c}\Delta \text { VSS } \\
(\mathrm{mg} / \mathrm{L})\end{array}$} & \multirow{3}{*}{$\begin{array}{c}\Delta \mathrm{NO}_{x}-\mathrm{N} \\
(\mathrm{mg} / \mathrm{L})\end{array}$} & \multirow{3}{*}{$\begin{array}{c}Y(\Delta \mathrm{VSS} / \\
\Delta \mathrm{NO}_{\left.3^{-}-\mathrm{N}\right)} \\
(\mathrm{g} / \mathrm{g})\end{array}$} & \multicolumn{4}{|c|}{$\begin{array}{c}\text { Parameter weighted average per } \\
\text { treatment }\end{array}$} \\
\hline & & & & \multicolumn{2}{|c|}{ VSS produced } & \multicolumn{2}{|c|}{$\mathrm{NO}_{3}{ }^{-}-\mathrm{N}$ removal } \\
\hline & & & & $\mathrm{kg} / \mathrm{d}$ & $\mathrm{kg} / \mathrm{m}^{3} \mathrm{~d}$ & $\mathrm{~kg} / \mathrm{d}$ & $\mathrm{kg} / \mathrm{m}^{3} \mathrm{~d}$ \\
\hline $1 \& 2$ (2:00 p.m.) & 9.17 & 7.49 & 1.24 & & & & \\
\hline $1 \& 2$ (10:00 p.m.) & 23.65 & 26.99 & 0.88 & 0.303 & 20.203 & 0.351 & 23.407 \\
\hline $1 \& 2$ (6:00 a.m.) & 27.50 & 29.40 & 0.94 & & & & \\
\hline $3 \& 4(2: 00$ p.m. $)$ & 6.50 & 4.18 & 1.58 & & & & \\
\hline $3 \& 4$ (10:00 p.m.) & 18.84 & 19.57 & 0.96 & 0.237 & 15.797 & 0.243 & 16.198 \\
\hline $3 \& 4$ (6:00 a.m.) & 18.67 & 19.91 & 0.95 & & & & \\
\hline
\end{tabular}

Table 12. Biological yields $\left(Y_{\text {NO3-N }}\right)$ data from denitrification reactor (steady state conditions) for each experimental working flow, VSS produced, and $\mathrm{NO}_{3}-\mathrm{N}$ removal.

higher reaction rates. Furthermore, these conditions could imply even higher nitrogen removal if recycling did not have to be employed in order to assure bed fluidization. Additionally, the reactor maintained a high VSS biomass concentration, around 38,000 $\mathrm{mg} / \mathrm{l}$. Under these conditions, the sand from the settled media on average represented only $17 \%$ of the settled bed volume in the reactor. This information would be critical for the design of sand denitrification filters to be operated under similar conditions.

\subsection{Estimation of operations costs for wastewater treatment at BRA}

Experimentation with the pilot station showed that by using these treatment strategies, water quality can be improved to the degree that treated effluent is safe for fish production. The commercial feasibility of effluent treatment and reuse, however, depends upon an assessment of benefits and costs. Estimation of the construction costs for a full-scale wastewater treatment station based on the pilot-scale design that we evaluated is beyond the scope of our study. Further, amortization of capital costs is highly variable among countries and times and hence is not well given to useful discussion. Operating costs, however, are estimable using data available to us. Operation of a scaled-up plant treating the entire BRA effluent of $2260 \mathrm{~m}^{3}$ /day would require electricity, oxygen for ozone production, methanol as a substrate for dentrification, ferric chloride for flocculation, and labor for operations and maintenance.

We assumed an ozone dose of $0.1 \mathrm{~g} / 1$ wastewater, about $15 \%$ higher than the dose applied in treatment 3 , the most successful treatment during pilot station experiments. Results of the pilot-scale study showed that such an increase should be economically feasible. This dose represents a total of $226 \mathrm{~kg} \mathrm{O}_{3} /$ day. At an average of $12.14 \mathrm{kWh}$ consumed per $\mathrm{kg}$ of ozone produced, the energy required daily will be $2743.6 \mathrm{kWh}$. At a local market price of $\$ 0.04 / \mathrm{kWh}$, the costs of producing ozone will be US\$110/day. Considering that the electricity required to operate the station is $10 \%$ of the energy required to produce ozone, total costs for electricity would be $\$ 120.75$ / day.

With current technology, which is capable of transforming $12 \%$ of oxygen into ozone, $1652.87 \mathrm{~m}^{3}$ of oxygen will be needed to produce the daily amount of ozone applied (i.e., 1.17 $\mathrm{m}^{3} \mathrm{O}_{2} / \mathrm{min}$ ). This volume is equivalent to $2257.6 \mathrm{~kg} \mathrm{O}_{2}$ (at $1.43 \mathrm{~kg} \mathrm{O}_{2} / \mathrm{m}^{3}$ ). Assuming oxygen recirculation and a supplemental loss of oxygen due to dissolution in water, oxygen consumption should be approximately $10 \%$ of the amount used. Hence, the cost of $225.8 \mathrm{~kg}$ of oxygen consumed daily will be $\$ 15.50 /$ day, at a bulk price of $\$ 0.092 / \mathrm{m}^{3}$. 
BRA releases $97 \mathrm{~kg} \mathrm{NO}_{3}-\mathrm{N}$ with the effluent, at an average concentration of $43 \mathrm{mg} / \mathrm{l}$. At an assumed methanol: $\mathrm{NO}_{3}{ }^{-} \mathrm{N}$ ratio of 3.2:1 required by denitrification, $310.4 \mathrm{~kg}$ methanol per day will be needed. At a methanol density of about $0.8 \mathrm{~kg} / \mathrm{l}, 388 \mathrm{~L}$ of methanol will be needed. Industrial grade methanol has a $98 \%$ concentration, which results in a total requirement of $396 \mathrm{~L}$. At a price of $\$ 0.50 / \mathrm{L}$, the cost of methanol will be $\$ 198 /$ day.

Jar tests showed that treatment with an average of $50 \mathrm{mg} \mathrm{FeCl} / 3 / 1$ wastewater, followed by sand filtration, could reduce the TSS in the treated effluent well below $10 \mathrm{mg} / \mathrm{l}$. At this dose, $113 \mathrm{~kg} \mathrm{FeCl}$ / day would be needed. At an average market price of $\$ 300 /$ metric ton $\mathrm{FeCl}_{3}$, the daily cost should be $\$ 34$.

The operation of a full-scale wastewater treatment station would require full-time labor, including weekends. This will add up to $56 \mathrm{hrs}$ of labor per week, or $240 \mathrm{hrs}$ per month. At an estimated wage of $\$ 10$ per hour, labor costs will add $\$ 2,400$ per month to costs.

Operation of the wastewater treatment system would minimize certain operations costs currently faced by BRA. Water temperature did not decrease by more than $1-1.5^{\circ} \mathrm{C}$ as water passed through the pilot station during the 3-4 hours of treatment. However, the pilot station was operated during the summer, and high environmental temperature could have affected the rate of temperature loss. Considering that the treatment station also would function during the winter and that water would be held in storage tanks before and after treatment, we assumed that temperature would decrease by as much as $7^{\circ} \mathrm{C}$. Because BRA spends between $\$ 10,000$ and $\$ 28,000$ per month (depending on season) on fuel oil to heat water, $75 \%$ heat recovery would represent $\$ 14,250$ per month in savings, from the current average of $\$ 19,000$. That is, only $\$ 4,750 /$ mo ( $\$ 158.33 /$ day) would be spent to bring replacement water to culture temperature, and $\$ 14,250$ per month would represent savings.

Releasing the waste stream instead of treating and reusing it adds to BRA's operating costs as wastewater discharge bill from the city of $\$ 14,000 /$ month $(\$ 467 /$ day). The energy to pump replacement water from the wells adds $\$ 450 /$ month (\$15/day) to operations costs. The summation of these costs results in total estimated expenses of $\$ 595.83 /$ day $(\$ 17,875 /$ month) for consumable materials. Against this total, $\$ 33,450$ is the actual average cost of heating the replacement water plus the municipal water treatment charge and the energy cost for pumping the water from the wells. Were the entire effluent reused, operations costs of wastewater treatment at BRA would be reduced by $\$ 15,575$ per month. Hence, much of the economic determination of whether to go forward with wastewater treatment and reuse will depend upon construction costs and the amortization into ongoing payments.

Our findings regarding costs and savings for treatment of effluent were such that BRA has gone forward with investment in full-scale effluent treatment. While the treatability of aquaculture effluent and the costs structure for treatment are specific to a given operation, the approach we took for assessing treatability and for designing and evaluating a treatment train are general, and will have relevance to a range of recirculating aquaculture system operations.

\section{Conclusion}

Recirculating aquaculture systems have been developed to produce high-value species for year-round supply of markets, to free production from site-related constraints, to minimize 
environmental impacts of aquaculture, and to make efficient use of limited high-quality water supplies. Effective treatment and reuse of aquaculture effluent has been demonstrated at an experimental scale. We built and operated a pilot-scale wastewater treatment station at a large commercial recirculating aquaculture facility in order to evaluate treatment strategies for effluent recovery and reuse. The treatment train consisted of sedimentation, denitrification, ozonation, nitrification and chemical flocculation. We report the dynamics of alkalinity, $\mathrm{pH}$, hardness and nitrogenous compounds through the treatment process. Alkalinity lost by water exchange was recovered due to nitrification, and alkalinity in treated effluent was $26-33 \%$ higher than initial alkalinity. $\mathrm{pH}$ increased from a mean of 7.21 in the initial influent to 7.60 in the final effluent after larger changes through the treatment train. Hardness decreased by approximately $10 \%$, with the degree of decrease positively correlated with ozone dose and with associated removal of total suspended solids. Up to $96 \%$ of total Kjeldall nitrogen was removed, mostly as organics. Although ammonia was produced during ozonation, it was partially removed in the trickling filter, decreasing by 35$40 \%$ after treatment. Over $94 \%$ of $\mathrm{NO}_{3}-\mathrm{N}$ was removed by the treatment train, declining to 2.0-2.7 mg/l. The biological yield for denitrification, $Y_{b}$ (g biomass volatile suspended solids/g $\mathrm{NO}_{3}^{-}-\mathrm{N}$ ), was 0.69 , and maximum nitrogen removal was $23.4 \mathrm{~kg} \mathrm{NO} 3^{-}-\mathrm{N} / \mathrm{m}^{3}$-day. The nitrogen removal in the denitrification reactor was between 16 and $23 \mathrm{~kg} \mathrm{NO} 3^{-}-\mathrm{N} / \mathrm{m}^{3}-$ day. Nitrogen removal was higher than generally expected from wastewater treatment, in part because of the high temperature of operation, $28-30^{\circ} \mathrm{C}$. We conclude that the pilot station design was effective for conserving alkalinity and hardness and for removing nutrients, and could be scaled up to treat and reuse the entire effluent stream. Should the system be scaled up, our results predict significant savings in operations costs, largely due to savings in energy required to heat the exchange water. While the treatability of aquaculture effluent and cost structure for treatment were specific to BRA, the approach we took to assess treatability and to evaluate the treatment train are general and will have applicability to a range of recirculating aquaculture system operations.

\section{Acknowledgement}

S.S. was supported by a Commercial Fish and Shellfish Technologies grant award to E.H. and by the Department of Fish and Wildlife Conservation at Virginia Polytechnic Institute and State University. We are grateful for access to the production facilities at Blue Ridge Aquaculture and to the water quality laboratory of the Department of Civil and Environmental Engineering at Virginia Tech University, and for the technical training and advice of Dr. Nancy Love and Julie Petruska.

\section{References}

APHA (American Public Health Association), American Water Works Association and Water Environment Federation (1998). Standard Methods for the Examination of Water and Wastewater, 20th edition. American Public Health Association, ISBN 0-87553-2357, Washington, DC

Beltran, F.J.; Garcia-Araya, J.F. \& Alvarez, P.M. (2001). pH sequential ozonation of domestic and wine-distillery wastewaters. Water Research, Vol. 35, No. 4, pp. 929-936, ISSN: 0043-1354 
Buxton, G.V.; Greenstock, C.L., Helman, W.P. \& Ross, A.B. (1988). Critical review of rate constants for reaction of hydrated electrons, hydrogen atoms and hydroxyl radicals $\left({ }^{\circ} \mathrm{OH} /{ }^{\circ} \mathrm{O}\right)$ ) in aqueous solutions. Journal of Physical Chemistry Reference Data, Vol. 17, No. 2, pp. 513-886, ISSN 0047-2689

Coelhoso, I.; Boaventura, R. \& Rodrigues, A. (1992). Biofilm reactors: An experimental and modeling study of wastewater denitrification in fluidized-bed reactors of activated carbon particles. Biotechnology and Bioengineering, Vol. 40, No. 5, pp. 625 - 633, ISSN 0006-3592

Grady, C.P.L.; Daigger, G.T. \& Lim H.C. (1999). Biological Wastewater Treatment, $2^{\text {nd }}$ edition. Marcel Dekker, Inc., New York, ISBN 0824789199

Grasso, D. \& Weber, W.J. (1988). Ozone-induced particle destabilization. Journal of the Water Works Association, Vol. 80, No. 8, pp. 73-81, ISSN 0003-150X

Jeris, J.S. \& Owens, R.W. (1975). Pilot-scale, high-rate biological denitrification. Journal of the Water Pollution Control Federation, Vol. 47, No. 8, pp. 2043-2057, ISSN 0431303

Jeris, J.S.; Owens, R.W. \& Hickey, R., (1977). Biological fluidized-bed treatment for BOD and nitrogen removal. Journal of the Water Pollution Control Federation Vol. 49, pp. 816831, ISSN 0043-1303

Karnchanawong, S. \& Polprasert, C. (1990). Organic carbon and nitrogen removal in attached-growth circulating reactor (AGCR). Water Science and Technology, Vol. 22, No. 3/4, pp. 179-186, ISSN 0273-1223

Kirk, B.S., McNabney, R. \& Wynn, C.S. (1975). Pilot plant studies of tertiary wastewater treatment with ozone. Ozone in water and wastewater treatment. In: F.L., Evans, editor. Pp. 61-82. Ann Arbor Science Publishers, Inc., ISBN 0250975238, Ann Arbor, MI

Lin, S.H. \& Wu, C.L. (1996). Removal of nitrogenous compounds from aqueous solution by ozonation and ion exchange. Water Research, Vol. 30, No. 8, pp. 1851-1857, ISSN: 0043-1354

Metcalf and Eddy, Inc. (1991). Wastewater Engineering: Treatment, Disposal and Reuse, $3^{\text {rd }}$ edition, McGraw-Hill, ISBN 0070416907, New York

Millamena, O.M. (1992). Ozone treatment of slaughterhouse and laboratory wastewaters. Aquacultural Engineering, Vol. 11, No. 1, pp. 23-31, ISSN 0144-8609

Moore, F. \& Schroeder, E.D. (1971). The effect of nitrification feed rate on denitrification. Water Research, Vol. 5, pp. 445-452, ISSN 0043-1354

Parker, D.S. \& Richards, T. (1986). Nitrification in trickling filters. Journal of the Water Pollution Control Federation, Vol. 58, No. 9, pp. 896-902, ISSN 0043-1303

Razumovskii, S.D., \& Zaikov, G.E., (1984). Ozone and its reactions with organic compounds. Elsevier Science Publishers B.V., ISBN 0444423699, Amsterdam

Rosenthal, H. \& Otte, G. (1979). Ozonation in an intensive fish culture recycling system. Ozone: Science and Engineering, Vol. 1, pp. 319 - 327, ISSN 0191-9512

Rueter, J. \& Johnson, R. (1995). The use of ozone to improve solids removal during disinfection. Aquacultural Engineering, Vol. 14, No. 2, pp. 123-141, ISSN 0144-8609

Sandu, S. (2004). Evaluation of ozone treatment, pilot-scale wastewater treatment plant, and nitrogen budget for Blue Ridge Aquaculture. Ph.D. dissertation. Virginia Polytechnic Institute and State University, Blacksburg, Virginia, USA

Sandu, S.; Brazil, B. \& Hallerman, E. (2008). Efficacy of a pilot-scale wastewater treatment plant upon a commercial aquaculture effluent: I. Solids and carbonaceous compounds. Aquacultural Engineering, Vol. 39, No. 1, pp. 78-90, ISSN 0144-8609 
Semon, J.; Sadick, T., Palumbo, D., Santoro, M. \& Keenan, P. (1997). Biological upflow fluidized bed denitrification reactor demonstration project - Stamford, CT, USA. Water Science and Technology, Vol. 36, No. 1, pp. 139-146, ISSN 0273-1223

Stephenson, J.P. \& Murphy, K.L. (1980). Kinetics of biological fluidized bed wastewater denitrification. Progressive Water Technology, Vol. 12, pp. 159 - 171

Summerfelt, S.T. (2003). Ozonation and UV irradiation - an introduction and examples of current applications. Aquacultural Engineering, Vol. 28, No. 1, pp. 21-36, ISSN 01448609

van Rijn, J. \& Rivera, G. (1990). Aerobic and anaerobic biofiltration in aquaculture. Unitnitrite accumulation as a result of nitrification. Aquacultural Engineering, Vol. 9, No. 2, pp. 217-234, ISSN 0144-8609

Wang, G.S. \& Pai, S.Y. (2001). Ozonation of dissolved organic matter in biologically treated wastewater effluents. Ozone: Science and Engineering, Vol. 23, pp. 351-358, ISSN 0191-9512 


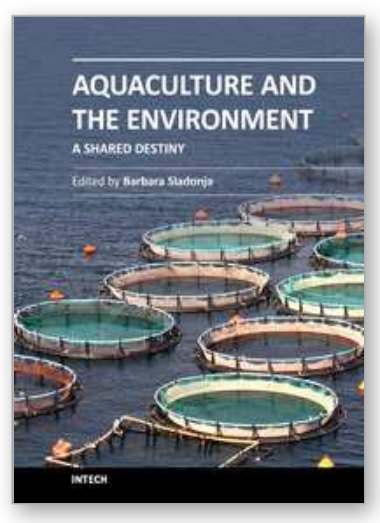

\author{
Aquaculture and the Environment - A Shared Destiny \\ Edited by Dr. Barbara Sladonja
}

ISBN 978-953-307-749-9

Hard cover, 246 pages

Publisher InTech

Published online 22, December, 2011

Published in print edition December, 2011

Aquaculture is the art, science and business of cultivating aquatic animals and plants in fresh or marine waters. It is the extension of fishing, resulted from the fact that harvests of wild sources of fish and other aquatic species cannot keep up with the increased demand of a growing human population. Expansion of aquaculture can result with less care for the environment. The first pre-requisite to sustainable aquaculture is clean wate, but bad management of aquatic species production can alter or even destroy existing wild habitat, increase local pollution levels or negatively impact local species. Aquatic managers are aware of this and together with scientists are looking for modern and more effective solutions to many issues regarding fish farming. This book presents recent research results on the interaction between aquaculture and environment, and includes several case studies all over the world with the aim of improving and performing sustainable aquaculture.

\title{
How to reference
}

In order to correctly reference this scholarly work, feel free to copy and paste the following:

Simonel Sandu, Brian Brazil and Eric Hallerman (2011). Efficacy of Pilot-Scale Wastewater Treatment upon a Commercial Recirculating Aquaculture Facility Effluent, Aquaculture and the Environment - A Shared Destiny, Dr. Barbara Sladonja (Ed.), ISBN: 978-953-307-749-9, InTech, Available from:

http://www.intechopen.com/books/aquaculture-and-the-environment-a-shared-destiny/efficacy-of-pilot-scalewastewater-treatment-upon-a-commercial-recirculating-aquaculture-facility-ef

\section{INTECH}

open science | open minds

\section{InTech Europe}

University Campus STeP Ri

Slavka Krautzeka 83/A

51000 Rijeka, Croatia

Phone: +385 (51) 770447

Fax: +385 (51) 686166

www.intechopen.com

\section{InTech China}

Unit 405, Office Block, Hotel Equatorial Shanghai

No.65, Yan An Road (West), Shanghai, 200040, China

中国上海市延安西路65号上海国际贵都大饭店办公楼405单元

Phone: +86-21-62489820

Fax: $+86-21-62489821$ 
(C) 2011 The Author(s). Licensee IntechOpen. This is an open access article distributed under the terms of the Creative Commons Attribution 3.0 License, which permits unrestricted use, distribution, and reproduction in any medium, provided the original work is properly cited. 